\title{
Holistic view on health : two protective layers of biodiversity
}

\section{Ruokolainen, Lasse}

2017-04

Ruokolainen , L , Lehtimaki , J , Karkman , A , Haahtela , T , von Hertzen , L \& Fyhrquist , N 2017 , ' Holistic view on health : two protective layers of biodiversity ' , Annales Zoologici Fennici , vol. 54 , no. 1-4 , pp. 39-49 . https://doi.org/10.5735/086.054.0106

http://hdl.handle.net/10138/225736

https://doi.org/10.5735/086.054.0106

cc_by

publishedVersion

Downloaded from Helda, University of Helsinki institutional repository.

This is an electronic reprint of the original article.

This reprint may differ from the original in pagination and typographic detail.

Please cite the original version. 


\title{
Holistic view on health: two protective layers of biodiversity
}

\author{
Lasse Ruokolainen ${ }^{1, *}$, Jenni Lehtimäki ${ }^{1}$, Antti Karkman ${ }^{1}$, Tari Haahtela ${ }^{2}$, \\ Leena von Hertzen ${ }^{2} \&$ Nanna Fyhrquist ${ }^{3}$
}
1) Department of Biosciences, P.O. Box 65, Fl-00014 University of Helsinki, Finland (*corresponding author's e-mail: lasse.ruokolainen@helsinki.fi)
2) Skin and Allergy Hospital, Helsinki University Central Hospital, P.O. Box 160, Fl-00029 HUCH, Finland
3) Department of Bacteriology and Immunology, P.O. Box 21, Fl-00014 University of Helsinki, Finland

Received 16 Sep. 2016, final version received 12 Oct. 2016, accepted 11 Oct. 2016

Ruokolainen, L., Lehtimäki, J., Karkman, A., Haahtela, T., von Hertzen, L. \& Fyhrquist, N. 2017: Holistic view on health: two protective layers of biodiversity. - Ann. Zool. Fennici 54: 39-49.

The western world has witnessed a rising epidemic of chronic inflammatory disorders, such as allergies and asthma. This epidemic is expected to spread also to the rest of the world, where allergies have to date been practically absent, along with adoption of western lifestyle. In parallel, biological diversity is globally declining. This inspired Ilkka Hanski, together with medical doctors, to formulate the biodiversity hypothesis of allergic disease. This hypothesis proposes that reduced contact with natural environments, including natural microbial diversity, is associated with unhealthy human microbiota, less able to educate the immune system. Contact with beneficial bacteria, particularly early in life, seems to be instrumental to the normal development of immune responses. Changes in lifestyle and diet, destruction of natural environments, and urbanisation threaten our natural exposure to these beneficial bacteria and thus also reduce their impact on our physiology. To ensure a healthy life, we need to preserve biodiversity in the environment and make sure it finds a favourable home in us. In this review, we will focus on the role of commensal microbiota in human health and wellbeing, as well as the interaction between our microbiota and environmental microbiota, highlighting the contribution of Ilkka Hanski.

\section{Introduction}

Life on earth is astoundingly variable. This biodiversity encompasses variation in form and function, as much within species as among species, and from the largest beings to the tiniest. Inspired by the work of May (1972), ecologists have long been interested in the relationship between ecosystem stability and species diversity. In theory, diversity can either be stabilising, destabilising, or unimportant depending, e.g., on the structuring of species communities (Fowler et al. 2012, Fowler \& Ruokolainen 2013). While theoretical models predict many scenarios, empirical data suggests that increasing diversity promotes stability through various mechanisms such as functional redundancy, broader utilisation of available resources, weak among-species interactions, and alternative energy channels (McCann 2000, Tilman et al. 2006, Rooney \& McCann 2012). 
Albeit the actual quantification of diversity has not been that clear (Tuomisto 2010), biologists have long been alarmed by the humandriven decline in macroscopic biological diversity, namely due to habitat destruction and fragmentation. However, we have been largely ignorant to diversity much greater than that visible to our bare eyes - by looking at the world through a microscope we would see nothing but bacteria. While these microscopic creatures can be found virtually everywhere in the environment, they also populate all multicellular life, including humans, to the extent that the number of bacteria in the gut of each human being exceeds the number of all humans to ever have walked this planet (Gould 1994). Despite their omnipresence, it has only relatively recently become clear that commensal/symbiotic bacteria are actively interacting with their hosts in a way that is of profound importance to individual wellbeing.

Symbiotic bacteria have been shown to affect the physiology, ecology, and evolution of their hosts in multiple ways (Shapira 2016). The composition of gut microbiota the collection of different bacteria - has been shown to affect nutrient acquisition, immune responses, and behaviour of the host (Broderick \& Lemaitre 2012). For example, mosquitos fail to develop without symbiotic bacteria (Coon et al. 2014), and the growth of herbivorous insects (Ruokolainen et al. 2016b), and the fecundity and pathogen resistance in nematodes (Dirksen et al. 2016) depend on the gut microbial composition. These examples suggest "evolved dependency", meaning that the host has lost some genetic potential, because symbionts have made the need for certain functions obsolete (Rook 2010). While work on the role of bacteria in natural populations is rapidly increasing, most studies still focus on human microbes.

During the past decades there was a sharp increase in the prevalence of inflammatory disorders, such as allergies and asthma, especially in the western society. There has been a long debate about the underlying mechanisms explaining this megatrend. In the late 1980s, it was suggested that childhood infections protect against allergies (Strachan 1989). While this has later been shown to be largely incorrect (Bloomfield et al. 2016), increased hygiene, improved sanitation, and medical preventive care have led to reduced human infection by helminth parasites, which is considered to be one of the key reasons behind the allergy epidemic (Yazdanbakhsh et al. 2002, Rottem et al. 2015, Spencer \& Zuk 2016). However, recent evidence suggest that the role of parasites is not independent of gut bacteria (Zaiss et al. 2015).

In 2011, ecologists and clinicians proposed that the two current megatrends - loss of biological diversity and increased incidence of allergies - could be related (von Hertzen et al. 2011). This idea led to the formulation of the "biodiversity hypothesis" related to the recent surge of allergic disease (Haahtela et al. 2013), in which the central idea is that the development of a healthy immune system, which is not reacting towards harmless allergens, relies on sufficient contact with beneficial bacteria in the natural environment (Ruokolainen et al. 2016a). According to recent evidence from twin studies, considerable variation in immune function among individuals is driven by non-heritable influences from the environment, most likely by many different microbes that an individuals encounters during their lifetime (Brodin et al. 2015).

Indeed, as noted above, bacteria are everywhere. As a consequence, we inhale them, swallow them, and touch them. This paints a complex picture of our lifetime exposure to the environmental biodiversity (Ruokolainen et al. 2016a). While only a small part of the encountered bacteria is able to permanently colonise our body, the composition of our microbiota is continuously affected by microbial invasion from the environment. In turn, this means that microbial diversity in our bodies intimately depends on the diversity of microbes we come to contact with, e.g., in our food and overall environment we live in. Given that our symbiotic bacteria help in building and maintaining a healthy immune defence, it can be thought that we are protected by two interacting layers of (microbial) biodiversity (Hanski 2014); an idea that is summarised in Fig. 1. In the following review, we will consider the constitution of our commensal microbial partners (the inner layer), the immunological role of these bacteria, and how our commensal communities are interacting with communities in the environment (the outer layer). 
Fig. 1. We (humans) are protected by two nested layers of biodiversity, consisting of bacteria (and other micro-organisms) residing in our bodies (both on the external and internal surfaces) and the one surrounding us in the environment we live in The diversity and composition of the inner layer is dependent on microbial colonisation from the outer layer; a process that is under the influence of our behaviour, lifestyle, environmental management, land-use planning, etc.

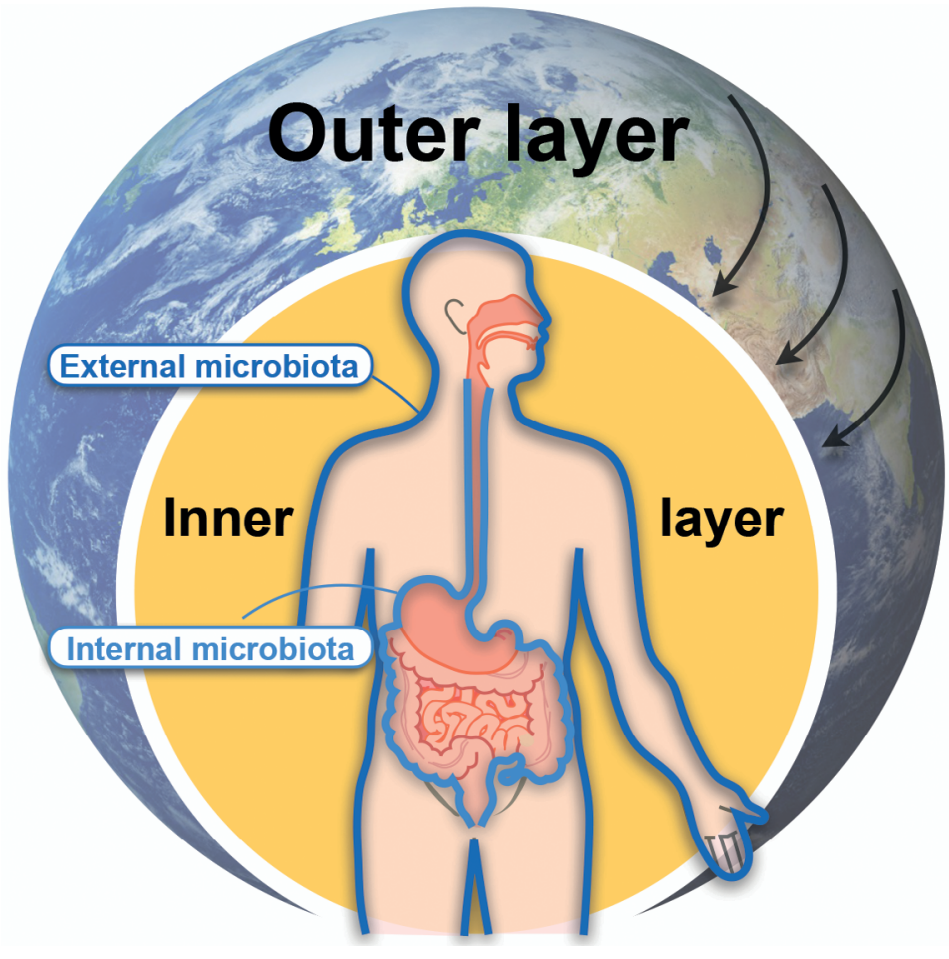

\section{The inner layer: diversity of the human indigenous microbiota}

The bacteria living in the human body are collectively referred to as microbiota, while the microbiota combined with their functionality in the body are called the microbiome. For long it was thought that the number of bacteria in the body exceeds the number of our own cells by an order of magnitude. While this has recently been shown to be an overestimate (the ratio is much closer to $1: 1$; Sender et al. 2016), the more than 3 million genes encoded in the genomes of our microbiota still dwarf the human genome's 23000 genes (Qin et al. 2010). Despite this overwhelming genetic diversity, the human microbiome tends to have high functional redundancy (Human Microbiome Project Consortium 2012), which is in contrast with the large variation within and between individuals in microbial composition. This is somewhat reassuring; the microbiome is functionally a robust provider of a multitude of important services to the body. However, one could argue that functional estimates are still lacking the finer-scale informa- tion, and thus some functions may be specific to some species or communities.

The journey of our microbial selves already begins in the womb, but a major colonisation takes place at birth (Rodríguez et al. 2015). This process can have important consequences to health in later life, a clear example being that children born through caesarean section have higher risk of developing allergies. This has been linked to the lack of exposure to the bacteria present in the birth canal (Rodríguez et al. 2015). While the gut microbiota converges to "normal" within the first year of life (Bäckhed et al. 2015) - namely due to cessation of breast-feeding, the critical period of immune system development already takes place during the first months of life (Arrieta et al. 2015). Luckily, there is a promise of a simple cure, by artificially inoculating the infants with vaginal bacteria (Dominguez-Bello et al. 2016).

The importance of the microbiota to human health has raised interest towards factors shaping the microbial composition. Due to differences in physical conditions, such factors are likely to differ across the human body. For example, the 
gut environment harbours a somewhat distinct and well defined community, e.g., in comparison with the skin, which is the most variable and diverse of all body habitats (Human Microbiome Project Consortium 2012). While the gut microbiota also tend to be rather stable through life (Ottman et al. 2012, Faith et al. 2013, David et al. 2014), some transient variation depending on daily activities also occurs (David et al. 2014). Not surprisingly, the key factor shaping the gut microbiota seems to be diet (e.g., Salonen \& de Vos 2014). Interestingly, the modulatory effect of diet on gut microbiota can also extend beyond generations (Myles et al. 2013). This is dramatically exemplified by recent results showing that sustained diet shifts can lead to a progressive, irreversible loss of horizontally transmitted symbiotic bacteria (Sonnenburg et al. 2016).

Other important factors contributing to variation in microbial composition include sex (Bolnick et al. 2014), age (e.g., Ottman et al. 2012), genetics (Goodrich et al. 2014), and the microbiota of other family members (Song et al. 2013). The composition of gut microbiota is clearly different between western and indigenous people, which is likely to be due to many lifestyle- and environment-related factors other than diet (De Filippo et al. 2010, Clemente et al. 2015). Prospective data obtained from humans regarding the role of living environment on gut microbiota are still lacking. Studies among immigrants might be fruitful in this respect, although the relative role of changed environmental microbiota and diet in the possible alterations of the gut communities can hardly be separated. Different body sites harbour clearly dissimilar microbes, which can be due to either differences in contact with microbial sources or dissimilar selection forces across sites (Costello et al. 2009). The skin microbiota are in closer contact with the environment than the gut, which is evident when comparing the similarity of different body habitats with, e.g., soil microbiota (Parfrey et al. 2015).

On the skin, there is a relative scarcity of microbes as compared with other body sites, due to the highly inhospitable environment, including variable temperatures, a low $\mathrm{pH}$, lack of nutrients, and high levels of salt and antimicrobial molecules. Nevertheless, there is a core population of microbes that thrive on the skin, with a variable element of transient inhabitants (Grice et al. 2009, Human Microbiome Project Consortium 2012). The skin provides a large number of diverse habitats with specialized niches, the conditions of which vary with skin thickness, folds, and the density of hair follicles and glands. Depending on skin topography, there are areas that are partially occluded and higher in temperature and humidity, as opposed to very dry areas, which are subjected to large surface temperature fluctuations. Sweat and sebaceous glands provide their unique microenvironments, bathing the skin in sweat or sebum, respectively. Thus, skin physiology is the main determinant of the pattern of colonization of the skin by microorganisms, with Staphylococcus and Corynebacterium inhabiting moist sites, lipophilic Propionibacterium dominating sebaceous areas, and Actinobacteria, Proteobacteria and Firmicutes occupying dry areas (Fyhrquist et al.2016).

Moreover, the community composition of the skin microbiota is shaped by the availability of nutrients and space, by the level of antimicrobial molecules produced by the host and other microbes, as well as by host immune responses and the extent to which these responses are modulated by other microbes. Microbial communities on the skin might be key players in host defence, with skin commensals directly protecting against pathogenic invaders, as well as helping the immune system to maintain a balance between protection and inflammation (Belkaid \& Segre 2014).

\section{The role of microbiota in disease; cross-talk between bacteria and immune system}

There are approximately $2 \mathrm{~kg}$ of bacteria in an adult human body, coming in contact with the host via over $30 \mathrm{~m}^{2}$ of epithelium (Helander \& Fändriks 2014). These commensals are no longer considered passive bystanders or transient passengers, but increasingly seen as active and essential participants in the development and maintenance of barrier function and immunological tolerance. Humans have evolved with these microorganisms, which are not recognised as pathogens which elicit defensive immune responses, but are 
rather part of immune regulatory circuits. They are also involved in the programming of many aspects of T-cell differentiation in co-operation with the host genome (Lee \& Mazmanian 2010). Protective mechanisms against inflammatory diseases involve the activation of the innate and regulatory networks by continuous exposure to microbial components via the skin, gut and respiratory tract (e.g., von Hertzen et al. 2011).

Dysbiosis, the reduced diversity and disturbed composition of the gut (and other) microbial community may have affected the occurrence of many inflammatory diseases such as asthma and allergies, type 1 diabetes, inflammatory bowel disease (IBD), obesity, and even psychiatric disorders, such as depression, being reported with increasing frequency in westernized countries (reviewed in Haahtela et al. 2013). Studies in both mice and humans indicate that some common members of the normal microbiota could play a special role in maintaining homeostasis and immune health (e.g., Frank et al.2007, Fujimura et al.2013, Fyhrquist et al. 2014). A decrease in absence of such microbes, such as many Lactobacilli, in the colon has been shown to lead to impaired development of regulatory $\mathrm{T}$ lymphocytes (Treg cells), the T-cell subset that mediates suppression of T-cell mediated inflammatory responses.

Toll-like receptors (TLR) are located on the surface of some innate immunity cells, and are used for recognising conserved structures in microbes. Signalling via TLRs and other conserved pattern-recognizing molecules that are present on various cells play a decisive role, not only in host defence against pathogens, but also to maintain epithelial cell homeostasis and tissue repair (Rakoff-Nahoum et al. 2004). This universal phenomenon has been shown in various tissues and occurs in wound healing (Bollyky et al. 2009). Evidence from mice highlights the role of TLR stimulation to confer protection against inflammatory conditions, supporting the epidemiological studies of human populations living in a microbe-rich environment. These effects were mediated by the induction of regulatory circuits and by stimulating innate immune mechanisms in epithelial cells (Pagnini et al. 2010).

An imbalance between 'pro-inflammatory' and 'anti-inflammatory' microbes may also result in an increased susceptibility of the host to inflammatory diseases and could explain, e.g., the increase in paediatric inflammatory bowel disease (IBD) (Lehtinen et al. 2011). A disruption of the signalling microbiota between TLR and other receptors cause immune dysfunction, enhancing the colonization and growth of a biased microbiota, thus creating a self-perpetuating circle to push the host-microbe interaction towards an 'unhealthy' state (von Hertzen et al. 2011). A concrete example of the central role of gut microbiota in health is that transplanting gut microbiota from an obese individual can result in obesity in the recipient, and horizontal transfer of microbiota from lean individuals can in turn transform the metabolic profile of obese microbiota to a lean-like state (Ridaura et al. 2013). Faecal microbiota transplant has also been successfully used to restore the balance of microbiota in severe Clostridium difficile infections (Surawicz \& Alexander 2011).

While most studies have focused on interplay between gut microbiota and immune system, also the skin flora has the ability to shape our immune responses. In genetically-predisposed individuals, various environmental factors may lead to inflammatory skin responses and impaired barrier function, as seen with chronic eczema (Cork et al. 2009). In contrast, it has been shown that certain skin bacteria can have a relatively strong immunoregulatory function (Hanski et al. 2012, Fyhrquist et al. 2014). A good example is the the genus Acinetobacter, which seems to play a key role in maintaining immune balance, by both suppressing and regulating immune gene expression (Fyhrquist et al. 2014).

\section{The interaction between the outer- and inner layers of microbial diversity}

As noted above, the initial inoculation of human microbiota mostly takes place at birth. However, this is not the case for most other animals. Placental mammals are usually born with their amniotic sacs (rarely also happens in humans), and large-scale microbial colonisation is initiated by the mother licking the infant after the amniotic sac has been removed. The primary 
source of colonizing microbiota in the animal kingdom is direct transmission from the environment - especially in aquatic animals (Mulder et al. 2009, Freese \& Schink 2011, Roeselers et al. 2011, Berg et al. 2016) - and from diet, which is the case, e.g., in herbivorous insects (Broderick et al. 2004, Robinson et al. 2010, Broderick \& Lemaitre 2012, Ruokolainen et al. 2016b). However, vertical transmission is also possible (Shapira 2016), such as the sharing of cellulolytic protozoans in termites (Lombardo 2008). As considered above, horizontal transfer is clearly important in humans (Arrieta et al. 2015, Bäckhed et al. 2015, Dominguez-Bello et al. 2016). Still, microbial colonization continues throughout life, with potential health outcomes (Ruokolainen et al. 2016a).

If we look back to the history of our species, the allergy epidemic can be seen to parallel the recent, rapid development in the human societies. Accelerating urbanisation and increasing cover of artificial surfaces reduce the opportunity for contact with environmental microbiota (Haahtela et al. 2015). This is supported by observations that children living in more green environments tend to have a lower risk to develop allergies (Hanski et al. 2012, Ruokolainen et al. 2015), which in turn agrees with observations that traditional farm environment tends to be protective (e.g., Lampi et al. 2011). Soil and plants - as well as fresh fruit, berries, and vegetables - are rich in Proteobacteria, with potential anti-inflammatory properties (von Hertzen 2015), which gives credence to the observed association between the living environment and health. Experiments on animals suggest that the living environment indeed affects the composition of gut microbiota (Mulder et al. 2009), which can in turn influence immune tolerance (Lewis et al. 2012, Pi et al. 2015).

However, it is not clear how generally the environment-health relationship observed in Finland (Ruokolainen et al. 2015) applies to different surroundings (Fuertes et al. 2016). While access to green space might be important, there is no guarantee that this opportunity is utilised. We spend more and more time indoors, where vacuum cleaners (Avershina et al. 2015), dishwashers (Hesselmar et al. 2015), and antimicrobial agents have contributed to impoverished microbial diversity. The indoor microbial environment strongly reflects that of the inhabitants being comprised mostly of human-derived skin bacteria (Lax et al. 2014, Barberán et al. 2015), rather than bacteria from the surrounding outdoor environment (Barberán et al. 2015). Still, the composition of the inhabitants, as well as the transfer of outdoor microbiota by different inhabitants, also affect indoor microbiota (Stamper et al. 2016). This means that such factors as lifestyle, behaviour, and social contacts (Tung et al. 2015) are likely to be relatively important for the dynamics of the microbiota in our immediate living environment as well as that in our bodies (David et al. 2014).

Reflecting back on our evolutionary history, recent results comparing wild and captive primates suggest that alteration in the lifestyle and living environment of captive animals lead to loss of native microbiota and convergence along an axis towards modern-human microbiota (Clayton et al. 2016). Interestingly, captive primates seem to resemble non-western humans, many of which have distinctively different gut microbiota from that of western humans (Schnorr et al. 2014, Clayton et al. 2016). Future work should compare immune tolerance in wild and captive animals to see whether the role of the living environment and lifestyle on health can be generalized.

Recently, an immunological mechanism has been demonstrated, through which bacterial endotoxin in farm dust can suppress type 2 (Th2) immune response in the lung (Schuijs et al. 2015). This highlights the protective role of the living environment and lifestyle in a somewhat specific manner, relying especially on contact with farm animals. However, there are potentially more subtle ways of enriching the microbiota in the immediate living environment. For example, having furry pets - dogs in particular - in the household significantly increase the microbial diversity in house dust (Fujimura et al. 2010, Barberán et al. 2015, Kettleson et al. 2015). Being in close contact with the ground, dogs are effective in sampling the environmental microbiota and introducing them indoors (Schaub \& Vercelli 2015). Oral administration of dog-associated house dust to mice has been shown to be allergy protective (Fujimura et al. 
2013) and there is also evidence suggesting that pet exposure modifies the infant gut microbiota in a protective manner (Nermes et al. 2015). Thus, having a pet is one potential solution for increasing the immune-supporting contact with environmental microbes.

\section{Synthesis}

Considering the critical role of early life exposure (Arrieta et al. 2015) - even before birth (Ruokolainen et al. 2016a), our health might largely boil down to the choices of our parents. At first, this might sound discouraging; do our own actions in later life bare no significance? However, it is clear that our living environment, physical activity, and diet affect our physical and mental health through life. Studies on immigration from countries with low allergy prevalence to western societies indicate that healthy immigrants can start to develop inflammatory disorders in the new environment, which could indicate that the immune system could be reprogrammed under sufficiently long and intense exposure (Garcia-Marcos et al. 2014).

What is also important to bear in mind is that even though the environment would be rich in beneficial bacteria, it does not help if our body - namely the gut but also the skin and the respiratory tract (Aho et al. 2015) - is a barren wasteland for these bacteria. For example, the gut environment is strongly affected by what we eat (Salonen \& de Vos 2014). Western diet rich in meat and simple sugars does not provide a favourable medium for those bacteria that promote our immune function by metabolising short-chained fatty acids from dietary fibre (Trompette et al. 2014, Richards et al. 2016).

The bacteria in our gut have been shown to be in a bi-directional interaction with our brain - via neural, endocrine, immune, and humoral links, known as the microbial gut-brain-axis (Carabotti et al. 2015). We propose here that we should also recognize a bi-directional environment-microbiota-health axis. Microbes that colonize us from the environment have the power to affect our health, whereas we hold the power to engineer the environment; both our inner as well as the one surrounding us. It follows that while it is important to preserve biological diversity for its own sake, we should also do it for our own sake. Not only are our livelihoods and societies dependent on the provisioning of ecosystem services (Costanza et al. 2014), but we also owe our health to the diversity of microbial life surrounding us. As the diversity of microbiota interacting with our immune system, as well as performing other vital functions in our bodies, ultimately arises from the microbiota present in our living environment, to preserve our inner biodiversity we also need to preserve the outer biodiversity. This is part of the legacy Ilkka Hanski - a tireless proponent of nature conservation - left us to remember. We hope this legacy is continued in research, but also that the idea of the environment-microbiota-health axis would be better recognized by policy makers.

\section{Acknowledgements}

We would like to thank Saskya van Nouhuys and Perttu Seppä for organising this species issue as a tribute to Ilkka Hanski, our dear mentor, colleague, and friend. We also want to thank an anonymous reviewer for their comments on the manuscript, and the Jane \& Aatos Erkko Foundation for financial support.

\section{References}

Aho, V. T., Pereira, P. A., Haahtela, T., Pawankar, R., Auvinen, P. \& Koskinen, K. 2015: The microbiome of the human lower airways: a next generation sequencing perspective. - World Allergy Organ. J. 8: 23, doi:10.1186/ s40413-015-0074-z.

Arrieta, M.-C., Stiemsma, L. T., Dimitriu, P. A., Thorson, L., Russell, S., Yurist-Doutsch, S., Gold, M. J., Brutten H. M., Lefebvre, D. L., Subbarao, P., Mandhane, P., Becker, A., McNagny, K. M., Sear, M. R., Kollman, T., CHIKD Study Investigators, Mohm, W. W., Turvey, S. E. \& Finlay, B. B. 2015: Early infancy microbial and metabolic alterations affect risk of childhood asthma. - Sci. Transl. Med. 7(307): 307ra152, doi:10.1126/ scitranslmed.aab2271.

Avershina, E., Ravi, A., Storrø, O., Øien, T., Johnsen, R. \& Rudi, K. 2015: Potential association of vacuum cleaning frequency with an altered gut microbiota in pregnant women and their 2-year-old children. - Microbiome 3: 65, doi:10.1186/s40168-015-0125-2.

Bäckhed, F., Roswall, J., Peng, Y., Feng, Q., Jia, H., Kovatcheva-Datchary, P., Li, Y., Xia, Y., Xie, H., Zhong, H., Khan, M.T., Zhang, J., Li., J., Xiao, L., Al-Aama, J., Zhang, D., Lee, Y.S., Kotowska, D., Conding, C., Trem- 
aroli, V., Yin, Y., Bergman, S., Xu, X., Madsen, L., Kristiansen, K., Dahlgren, J. \& Wang, J. 2015: Dynamics and stabilization of the human gut microbiome during the first year of life. - Cell Host Microbe. 17: 690-703.

Barberán, A., Dunn, R. R., Reich, B. J., Pacifici, K., Laber, E. B., Menninger, H. L., Morton, J. M., Henley, J. B., Leff, J. W., Miller, S. L. \& Fierer, N. 2015: The ecology of microscopic life in household dust. - Proc. R. Soc. B 282(1814), 20151139, doi:10.1098/rspb.2015.1139.

Belkaid, Y. \& Segre, J. A. 2014: Dialogue between skin microbiota and immunity. - Science 346: 954-959.

Berg, M., Stenuit, B., Ho, J., Wang, A., Parke, C., Knight, M., Alvarez-Cohen, L. \& Shapira, M. 2016: Assembly of the Caenorhabditis elegans gut microbiota from diverse soil microbial environments. - ISME J. 10: 1998-2009.

Bloomfield, S. F., Rook, G. A., Scott, E. A., Shanahan, F., Stanwell-Smith, R. \& Turner, P. 2016: Time to abandon the hygiene hypothesis: new perspectives on allergic disease, the human microbiome, infectious disease prevention and the role of targeted hygiene. - Perspect. Public Health 136: 213-224.

Bollyky, P. L., Bice, J. B., Sweet, I. R., Falk, B. A., Gebe, J. A., Clark, A. E., Gersuk, V. H., Aderem, A., Hawn, T. R. \& Nepom, G. T. 2009: The toll-like receptor signaling molecule Myd88 contributes to pancreatic beta-cell homeostasis in response to injury. - PloS One 4(4): e5063, doi:10.1371/journal.pone.0005063.

Bolnick, D. I., Snowberg, L. K., Hirsch, P. E., Lauber, C. L., Org, E., Parks, B., Lusis, A. J., Knight, R., Caporaso, J. G. \& Svanbäck, R. 2014: Individual diet has sex-dependent effects on vertebrate gut microbiota. - Nature Communications 5, 4500, doi:10.1038/ncomms5500.

Broderick, N. A. \& Lemaitre, B. 2012: Gut-associated microbes of Drosophila melanogaster. - Gut Microbes 3: 307-321.

Broderick, N. A., Raffa, K. F., Goodman, R. M. \& Handelsman, J. 2004: Census of the bacterial community of the gypsy moth larval midgut by using culturing and culture-independent methods. - Appl. Environ. Microbiol. 70: 293-300.

Brodin, P., Jojic, V., Gao, T., Bhattacharya, S., Angel, C. J. L., Furman, D., Shen-Orr, S., Dekker, C. L., Swan, G. E., Butte, A. J., Maecker, H. T. \& Davis, M. M. 2015: Variation in the human immune system is largely driven by non-heritable influences. - Cell 160: 37-47.

Carabotti, M., Scirocco, A., Maselli, M. A. \& Severi, C. 2015: The gut-brain axis: interactions between enteric microbiota, central and enteric nervous systems. - Ann. Gastroenterol. 28: 203-209.

Clayton, J. B., Vangay, P., Huang, H., Ward, T., Hillmann, B. M., Al-Ghalith, G. A., Travis, D. A., Long, H. T., Tuan, B. V., Minh, V. V., Cabana, F., Nadler, T., Toddles, B., Murphy, T., Glander, K. E., Johnson, T. J. \& Knights, D. 2016: Captivity humanizes the primate microbiome. Proc. Natl. Acad. Sci. USA 113: 10376-10981.

Clemente, J. C., Pehrsson, E. C., Blaser, M. J., Sandhu, K., Gao, Z., Wang, B., Mgris, M., Hidalgo, G., Contreras, M., Noya-Alarcon, Ó., Lander, O., McDonald, J., Cox, M., Walter, J., Oh, P. L., Ruiz, J. F., Rodriques, S., Shen, N., Song, S. J., Metcalf, J., Knight, R., Dantas, G. \&
Dominiquez-Bello, M. G. 2015: The microbiome of uncontacted Amerindians. - Sci. Adv. 1(3), e1500183, doi:10.1126/sciadv.1500183.

Coon, K. L., Vogel, K. J., Brown, M. R. \& Strand, M. R. 2014: Mosquitoes rely on their gut microbiota for development. - Mol. Ecol. 23: 2727-2739.

Cork, M. J., Danby, S. G., Vasilopoulos, Y., Hadgraft, J., Lane, M. E., Moustafa, M., Guy, R. H., MacGowan, A. L., Tazi-Ahnini, R. \& Ward, S. J. 2009: Epidermal barrier dysfunction in atopic dermatitis. - J. Invest. Dermatol. 129: 1892-1908.

Costanza, R., de Groot, R., Sutton, P., van der Ploeg, S., Anderson, S. J., Kubiszewski, I., Farber, S. \& Turner, R. K. 2014: Changes in the global value of ecosystem services. - Glob. Environ. Change 26: 152-158.

Costello, E. K., Lauber, C. L., Hamady, M., Fierer, N., Gordon, J. I. \& Knight, R. 2009: Bacterial community variation in human body habitats across space and time. - Science 18: 1694-1697.

David, L. A., Materna, A. C., Friedman, J., Campos-Baptista, M. I., Blackburn, M. C., Perrotta, A., Erdman, S. E. \& Alm, E. J. 2014: Host lifestyle affects human microbiota on daily timescales. - Genome Biol. 15: R89, doi:10.1186/gb-2014-15-7-r89.

De Filippo, C., Cavalieri, D., Di Paola, M., Ramazzotti, M., Poullet, J. B., Massart, S., Collini, S., Pieraccini, G. \& Lionetti, P. 2010: Impact of diet in shaping gut microbiota revealed by a comparative study in children from Europe and rural Africa. - Proc. Natl. Acad. Sci. USA 107: 14691-14696.

Dirksen, P., Marsh, S. A., Braker, I., Heitland, N., Wagner, S., Nakad, R., Mader, S., Petersen, C., Kowallik, V., Rosenstiel, P., Félix, M. A. \& Schulenbug, H. 2016: The native microbiome of the nematode Caenorhabditis elegans: gateway to a new host-microbiome model. - BMC Biol. 14: 38, doi:10.1186/s12915-016-0258-1.

Dominguez-Bello, M. G., De Jesus-Laboy, K. M., Shen, N., Cox, L. M., Amir, A., Gonzalez, A., Bokulich, N. A., Song, S. J., Hoashi, M., Rivera-Vinas, J. I., Mendez, K., Knight, R. \& Clemente, J. C. 2016: Partial restoration of the microbiota of cesarean-born infants via vaginal microbial transfer. - Nat. Med. 22: 250-253.

Faith, J. J., Guruge, J. L., Charbonneau, M., Subramanian, S., Seedorf, H., Goodman, A. L., Knight, R., Heath, A. C., Leibel, R. L., Rosenbaum, M. \& Gordon, J. I. 2013: The long-term stability of the human gut microbiota. - Science 341, 6141, doi:10.1126/science.1237439.

Fowler, M. S., Laakso, J., Kaitala, V., Ruokolainen, L. \& Ranta, E. 2012: Species dynamics alter community diversity-biomass stability relationships. - Ecol. Lett. 15: 1387-1396.

Fowler, M. S. \& Ruokolainen, L. 2013: Colonization, covariance and colour: environmental and ecological drivers of diversity-stability relationships. - J. Theor. Biol. 324: $32-41$.

Frank, D. N., Amand, A. L. S., Feldman, R. A., Boedeker, E. C., Harpaz, N. \& Pace, N. R. 2007: Molecular-phylogenetic characterization of microbial community imbalances in human inflammatory bowel diseases. - Proc. Natl. Acad. Sci. USA 104: 13780-13785. 
Freese, H. M. \& Schink, B. 2011: Composition and stability of the microbial community inside the digestive tract of the aquatic crustacean Daphnia magna. - Microb. Ecol. 62: 882-894.

Fuertes, E., Markevych, I., Bowatte, G., Gruzieva, O., Gehring, U., Becker, A., Berdel, D., von Berg, A., Bergström, A., Bauer, M., Brunekreef, B., Brüske, I., Carlsten, C., Chan-Yeng, M., Dharmage, S. C., Hoffman, B., Klümper, C., Koppelman, G. H., Kozyrskyi, A., Korek, M., Kull, I., Lodge, C., Lowe, A., MacIntyre, E., Pershagen, G., Standi, M., Sugiri, D., Wiiga, A., MACS \& Heinrich, J. 2016: Residential greenness is differentially associated with childhood allergic rhinitis and aeroallergen sensitization in seven birth cohorts. - Allergy 71 : 1461-1471.

Fujimura, K. E., Demoor, T., Rauch, M., Faruqi, A. A., Jang, S., Johnson, C. C., Boushey, H. A., Zoratti, E., Ownby, D., Lukacs, N. W. \& Lynch, S. V. 2013: House dust exposure mediates gut microbiome Lactobacillus enrichment and airway immune defense against allergens and virus infection. - Proc. Natl. Acad. Sci. USA 111: 805-810.

Fujimura, K. E., Johnson, C. C., Ownby, D. R., Cox, M. J., Brodie, E. L., Havstad, S. L., Zoratti, E. M., Woodcroft, K. J., Bobbit, K. R., Wegienca, G., Boushey, H. A. \& Lynch, S. V. 2010: Man's best friend? The effect of pet ownership on house dust microbial communities. $-J$. Allergy Clin. Immunol. 126: 410-412.

Fyhrquist, N., Ruokolainen, L., Suomalainen, A., Lehtimäki, S., Veckman, V., Vendelin, J., Karisola, P., Lehto, M., Savinko, T., Jarva, H., Kosunen, T. U., Corander, J., Auvinen, P., Paulin, L., von Hertzen, L., Laatikainen, T., Mäkelä, M., Haahtela, T., Greco, D., Hanski, I. \& Alenius, H. 2014: Acinetobacter species in the skin microbiota protect against allergic sensitization and inflammation. - J. Allergy Clin. Immunol. 134: 1301-1309.

Fyhrquist, N., Salava, A., Auvinen, P. \& Lauerma, A. 2016: Skin biomes. - Curr. Allergy Asthma Rep. 16(5): 40, doi:10.1007/s11882-016-0618-5.

Garcia-Marcos, L., Robertson, C. F., Anderson, H. R., Ellwood, P., Williams, H. C., Wong, G. W. \& ISAAC Phase Study Group 2014: Does migration affect asthma, rhinoconjunctivitis and eczema prevalence? Global findings from the international study of asthma and allergies in childhood. - Int. J. Epidemiol. 43: 1846-1854.

Goodrich, J. K., Waters, J. L., Poole, A. C., Sutter, J. L., Koren, O., Blekhman, R., van Treuren, W., Knight, R., Bell, J. T., Spector, T. D., Clark, A. G. \& Ley, R. E. 2014: Human genetics shape the gut microbiome. Cell 159: 789-799.

Gould, S. J. 1994: The evolution of life on the Earth. - Sci. Am. 271: 84-91.

Grice, E. A., Kong, H. H., Conlan, S., Deming, C. B., Davis, J., Young, A. C., NISC Comparative Sequencing Program, Bouffard, G. G., Blakesley, R. W., Murray, P. R., Green, E. D., Turner, M. L. \& Segre, J. A. 2009: Topographical and temporal diversity of the human skin microbiome. - Science 324: 1190-1192.

Haahtela, T., Holgate, S., Pawankar, R., Akdis, C. A., Benjaponpitak, S., Caraballo, L., Demain, J., Portnoy, J \& von Hertzen, L. 2013: The biodiversity hypothesis and allergic disease: world allergy organization position statement. - World Allergy Organ. J. 6(1): 3, doi:10.1186/1939-4551-6-3.

Haahtela, T., Laatikainen, T., Alenius, H., Auvinen, P., Fyhrquist, N., Hanski, I., von Hertzen, L., Jousilahti, P., Kosunen, T. U., Markelova, O., Mäkelä, M. J., Pantelejev, V., Uhanov, M., Zilber, E. \& Vartiainen, E. 2015: Hunt for the origin of allergy-comparing the Finnish and Russian Karelia. - Clin. Exp. Allergy 45: 891-901.

Hanski, I. 2014: Biodiversity, microbes and human wellbeing. - Ethics Sci. Environ. Polit. 14: 19-25.

Hanski, I., von Hertzen, L., Fyhrquist, N., Koskinen, K., Torppa, K., Laatikainen, T., Karisola, P., Auvinen, P., Paulin, L., Mäkelä, M. J., Vartiainen, E., Kosunen, T. U., Laenius, H. \& Haahtela, T. 2012: Environmental biodiversity, human microbiota, and allergy are interrelated. - Proc. Natl. Acad. Sci. USA 109: 8334-8339.

Helander, H. F. \& Fändriks, L. 2014: Surface area of the digestive tract - revisited. - Scand. J. Gastroenterol. 49: 681-689.

Hesselmar, B., Hicke-Roberts, A. \& Wennergren, G. 2015: Allergy in children in hand versus machine dishwashing. - Pediatrics 135, doi:10.1542/peds.2014-2968.

Human Microbiome Project Consortium 2012: Structure, function and diversity of the healthy human microbiome. - Nature 486: 207-214.

Kettleson, E. M., Adhikari, A., Vesper, S., Coombs, K., Indugula, R. \& Reponen, T. 2015: Key determinants of the fungal and bacterial microbiomes in homes. - Environ. Res. 138: 130-135.

Lampi, J., Canoy, D., Jarvis, D., Hartikainen, A.-L., KeskiNisula, L., Järvelin, M.-R. \& Pekkanen, J. 2011: Farming environment and prevalence of atopy at age 31 : prospective birth cohort study in Finland. - Clin. Exp. Allergy 41: 987-993.

Lax, S., Smith, D. P., Hampton-Marcell, J., Owens, S. M., Handley, K. M., Scott, N. M., Gibbons, S. M., Larsen, P., Shogan, B. D., Weiss, S., Metcalf, J. L., Ursell, L. K., Vázques-Baesa, Y., Van Treuren, W., Hasan, N. A., Gibson, M. K., Colwell, R., Dantas, G., Knight, R. \& Gilbert, J. A. 2014: Longitudinal analysis of microbial interaction between humans and the indoor environment. - Science 345: 1048-1052.

Lee, Y. K. \& Mazmanian, S. K. 2010: Has the microbiota played a critical role in the evolution of the adaptive immune system? - Science 330: 1768-1773.

Lehtinen, P., Ashorn, M., Iltanen, S., Jauhola, R., Jauhonen, P., Kolho, K.-L. \& Auvinen, A. 2011: Incidence trends of pediatric inflammatory bowel disease in Finland, 1987-2003, a nationwide study. - Inflamm. Bowel Dis. 17: $1778-1783$.

Lewis, M. C., Inman, C. F., Patel, D., Schmidt, B., Mulder, I., Miller, B., Gill, B. P., Pluske, J., Kelly, D., Stokes, C. R. \& Bailey, M. 2012: Direct experimental evidence that early-life farm environment influences regulation of immune responses. - Pediatr. Allergy Immunol. 23: 265-269.

Lombardo, M. P. 2008: Access to mutualistic endosymbiotic microbes: an underappreciated benefit of group living. - Behav. Ecol. Sociobiol. 62: 479-497. 
May, R. M. 1972: Will a large complex system be stable? Nature 238: 413-414.

McCann, K. S. 2000: The diversity-stability debate. Nature 405: 228-233.

Mulder, I. E., Schmidt, B., Stokes, C. R., Lewis, M., Bailey, M., Aminov, R. I., Prosser, J. I., Gill, B. P., Pluske, J. R., Mayer, C.-D., Musk, C. C. \& Kelly, D. 2009: Environmentally-acquired bacteria influence microbial diversity and natural innate immune responses at gut surfaces. BMC Biol. 7: 79, doi:10.1186/1741-7007-7-79.

Myles, I. A., Fontecilla, N. M., Janelsins, B. M., Vithayathil, P. J., Segre, J. A. \& Datta, S. K. 2013: Parental dietary fat intake alters offspring microbiome and immunity. J. Immunol. 191: 3200-3209.

Nermes, M., Endo, A., Aarnio, J., Salminen, S. \& Isolauri, E. 2015: Furry pets modulate gut microbiota composition in infants at risk for allergic disease. - J. Allergy Clin. Immunol. 136: 1688-1690.

Ottman, N., Smidt, H., De Vos, W. M. \& Belzer, C. 2012: The function of our microbiota: who is out there and what do they do? - Front. Cell. Infect. Microbiol. 2: 104, doi:10.3389/fcimb.2012.00104.

Pagnini, C., Saeed, R., Bamias, G., Arseneau, K. O., Pizarro, T. T. \& Cominelli, F. 2010: Probiotics promote gut health through stimulation of epithelial innate immunity. - Proc. Natl. Acad.Sci. USA 107: 454-459.

Parfrey, L. W., Walters, W. A., Lauber, C. L., Clemente, J. C., Berg-Lyons, D., Teiling, C., Kodira, C., Mohiuddin, M., Brunelle, J., Driscoll, M., Fierer, N., Gilbert, J. A. \& Knight, R. 2015: Communities of microbial eukaryotes in the mammalian gut within the context of environmental eukaryotic diversity. - Roles Mech. Parasit. Aquat. Microb. Communities 5: 298, doi:10.3389/ fmicb.2014.00298.

Pi, C., Allott, E. H., Ren, D., Poulton, S., Lee, S. R., Perkins, S., Everett, M. L., Holzknecht, Z. E., Lin, S. S. \& Parker, W. 2015: Increased biodiversity in the environment improves the humoral response of rats. - PLoS One 10(4): e0120255, doi:10.1371/journal.pone.0120255.

Qin, J., Li, R., Raes, J., Arumugam, M., Burgdorf, K. S., Manichanh, C., Nielsen, T., Pons, N., Levenez, F., Yamada, T., Mende, D. R., Li, J., Xu, J., Li, S., Li, D., Cao, J., Wang, B., Liang, H., Zheng, H., Xie, Y., Tap, J., Lepage, P., Bertalan, M., Batto, J.-M., Hansen, T., Le Paslier, D., Linneberg A., Nielsen, H. B., Pelletier, E., Renault, P., Sicheritz-Ponten, T., Turner, K., Zhu, H., Yu, C., Li, S., Jian, M., Zhou, Y., Li, Y., Zhang, X., Li, S., Qin, N., Yang, H., Wang, J., Brunak, S., Doré, J., Guarner, F., Kristiansen, K., Pedersen, O., Parkhill, J., Weissenbach, J., MetaHIT Consortium, Bork, P., Ehrlich, S. D. \& Wang, J. 2010: A human gut microbial gene catalogue established by metagenomic sequencing. - Nature 464: 59-65.

Rakoff-Nahoum, S., Paglino, J., Eslami-Varzaneh, F., Edberg, S. \& Medzhitov, R. 2004: Recognition of commensal microflora by toll-like receptors is required for intestinal homeostasis. - Cell 118: 229-241.

Richards, J. L., Yap, Y. A., McLeod, K. H., Mackay, C. R. \& Mariño, E. 2016: Dietary metabolites and the gut microbiota: an alternative approach to control inflammatory and autoimmune diseases. - Clin. Transl. Immunol. 5: e82, doi:10.1038/cti.2016.29.

Ridaura, V. K., Faith, J. J., Rey, F. E., Cheng, J., Duncan, A. E., Kau, A. L., Griffin, N. W., Lombard, V., Henrissat, B., Bain, J. R., Muehlbauer M. J., Ilkayeva, O., Semenkovich, C. F., Funai, K., Hayashi, D. K., Lyle, B. J., Martini, M. C., Ursell, L. K., Clemente, J. C., Van Treuren, M., Walters, W. A., Knight, R., Newgard, C. B., Heath, A. C. \& Gordon, J. I. 2013: Gut microbiota from twins discordant for obesity modulate metabolism in mice. Science 341(6150), doi:10.1126/science.1241214.

Robinson, C. J., Schloss, P., Ramos, Y., Raffa, K. \& Handelsman, J. 2010: Robustness of the bacterial community in the cabbage white butterfly larval midgut. - Microb. Ecol. 59: 199-211.

Rodríguez, J. M., Murphy, K., Stanton, C., Ross, R. P., Kober, O. I., Juge, N., Avershina, E., Rudi, K., Narbad, A., Jenmalm, M. C., Marchesi, J. R. \& Collado, M. C. 2015: The composition of the gut microbiota throughout life, with an emphasis on early life. - Microb. Ecol. Health Dis. 26: 26050, doi:10.3402/mehd.v26.26050.

Roeselers, G., Mittge, E. K., Stephens, W. Z., Parichy, D. M., Cavanaugh, C. M., Guillemin, K. \& Rawls, J. F. 2011: Evidence for a core gut microbiota in the zebrafish. ISME J. 5: 1595-1608.

Rook, G. A. W. 2010: 99th Dahlem conference on infection, inflammation and chronic inflammatory disorders: Darwinian medicine and the "hygiene"or "old friends" hypothesis. - Clin. Exp. Immunol. 160: 70-79.

Rooney, N. \& McCann, K. S. 2012: Integrating food web diversity, structure and stability. - Trends Ecol. Evol. 27: 40-46.

Rottem, M., Geller-Bernstein, C. \& Shoenfeld, Y. 2015: Atopy and asthma in migrants: the function of parasites. - Int. Arch. Allergy Immunol. 167: 41-46.

Ruokolainen, L., Fyhrquist, N. \& Haahtela, T. 2016a: The rich and the poor: environmental biodiversity protecting from allergy. - Curr. Opin. Allergy Clin. Immunol. 16: 421-426.

Ruokolainen, L., Hertzen, L., Fyhrquist, N., Laatikainen, T., Lehtomäki, J., Auvinen, P., Karvonen, A. M., Hyvärinen, A., Tillmann, V., Niemelä, O., Knip, M., Haahtela, T., Pekkanen, J. \& Hanski, I. 2015: Green areas around homes reduce atopic sensitization in children. - Allergy 70: 195-202.

Ruokolainen, L., Ikonen, S., Makkonen, H. \& Hanski, I. 2016b: Larval growth rate is associated with the composition of the gut microbiota in the Glanville fritillary butterfly. - Oecologia 181: 895-903.

Salonen, A. \& de Vos, W. M. 2014: Impact of diet on human intestinal microbiota and health. - Annu. Rev. Food Sci. Technol. 5: 239-262.

Schaub, B. \& Vercelli, D. 2015: Environmental protection from allergic diseases: from humans to mice and back. - Curr. Opin. Immunol. 36: 88-93.

Schnorr, S. L., Candela, M., Rampelli, S., Centanni, M., Consolandi, C., Basaglia, G., Turroni, S., Biagi, E., Peano, C., Severgnini, M., Fiori, J., Gotti, R., De Bellis, G., Luiselli, D., Brigidi, P., Madulla, A., Marlowe, F., Henry, A. G. \& Crittenden, A. N. 2014: Gut microbiome 
of the Hadza hunter-gatherers. - Nature Communications 5: 3654, doi:10.1038/ncomms4654.

Schuijs, M. J., Willart, M. A., Vergote, K., Gras, D., Deswarte, K., Ege, M. J., Madeira, F. B., Beyaert, R., van Loo, G., Bracher, F., von Mutius, E., Chanez, P., Lambrecht, B. N. \& Hammad, H. 2015: Farm dust and endotoxin protect against allergy through A20 induction in lung epithelial cells. - Science 349: 1106-1110.

Sender, R., Fuchs, S. \& Milo, R. 2016: Revised estimates for the number of human and bacteria cells in the body. - PLoS Biology 14(8): e1002533, doi:10.1371/journal. pbio.1002533.

Shapira, M. 2016: Gut microbiotas and host evolution: scaling up symbiosis. - Trends Ecol. Evol. 31: 539-549.

Song, S. J., Lauber, C., Costello, E. K., Lozupone, C. A., Humphrey, G., Berg-Lyons, D., Caporaso, J. G., Knights, D., Clemente, J. C., Nakielny, S., Gordon, J. I., Fierer, N. \& Knight, R. 2013: Cohabiting family members share microbiota with one another and with their dogs. - eLife 2: e00458, doi:10.7554/eLife.00458.

Sonnenburg, E. D., Smits, S. A., Tikhonov, M., Higginbottom, S. K., Wingreen, N. S. \& Sonnenburg, J. L. 2016: Diet-induced extinctions in the gut microbiota compound over generations. - Nature 529: 212-215.

Spencer, H. G. \& Zuk, M. 2016: For host's sake: the pluses of parasite preservation. - Trends Ecol. Evol. 31: 341-343.

Stamper, C. E., Hoisington, A. J., Gomez, O. M., HalwegEdwards, A. L., Smith, D. G., Bates, K. L., Kinney, K. A., Postolache, T. T., Brenner, L. A., Rook, G. A. W. \& Lowry, C. A. 2016: The microbiome of the built environment and human behavior: implications for emotional health and well-being in postmodern western societies. Int. Rev. Neurobiol. 131: 289-323.

Strachan, D. P. 1989: Hay fever, hygiene, and household size. - BMJ 299: 1259-1260.

Surawicz, C. M. \& Alexander, J. 2011: Treatment of refrac- tory and recurrent Clostridium difficile infection. - Nat. Rev. Gastroenterol. Hepatol. 8: 330-339.

Tilman, D., Reich, P. B. \& Knops, J. M. H. 2006: Biodiversity and ecosystem stability in a decade-long grassland experiment. - Nature 441: 629-632.

Trompette, A., Gollwitzer, E. S., Yadava, K., Sichelstiel, A. K., Sprenger, N., Ngom-Bru, C., Blanchard, C., Junt, T., Nicod, L. P., Harris, N. L. \& Marsland, B. J. 2014: Gut microbiota metabolism of dietary fiber influences allergic airway disease and hematopoiesis. - Nat. Med. 20: $159-166$.

Tung, J., Barreiro, L. B., Burns, M. B., Grenier, J.-C., Lynch, J., Grieneisen, L. E., Altmann, J., Alberts, S. C., Blekhman, R. \& Archie, E. A. 2015: Social networks predict gut microbiome composition in wild baboons. - elife 4: e05224, doi:10.7554/eLife.05224.

Tuomisto, H. 2010: A consistent terminology for quantifying species diversity? Yes, it does exist. - Oecologia 164: 853-860.

von Hertzen, L. 2015: Plant microbiota: implications for human health. - Br. J. Nutr. 114: 1531-1532.

von Hertzen, L., Hanski, I. \& Haahtela, T. 2011: Natural Immunity: Biodiversity loss and inflammatory diseases are two global megatrends that might be related. EMBO Reports 12: 1089-1093.

Yazdanbakhsh, M., Kremsner, P. G. \& van Ree, R. 2002: Allergy, parasites, and the hygiene hypothesis. - Science 296: 490-494.

Zaiss, M. M., Rapin, A., Lebon, L., Dubey, L. K., Mosconi, I., Sarter, K., Piersigilli, A., Menin, L., Walker, A. W., Rougemont, J., Paerewijck, O., Geldhof, P., McCoy, K. D., Macpherson, A. J., Croese, J., Giacomin, P. R., Loukas, A., Junt, T., Marsland, B. J. \& Harris, N. L. 2015: The intestinal microbiota contributes to the ability of helminths to modulate allergic inflammation. Immunity 43: 998-1010. 